\title{
PARASITOLOGICAL AND SEROLOGICAL STUDY ON FASCIOLA DIAGNOSIS IN CATTLE AND BUFFALOES IN ASSIUT GOVERNORATE
}

\author{
HUDA M. KURAA* ${ }^{*}$ and SAFAA S. MALEK ${ }^{* *}$ \\ *Animal Health Research Institute, Assiut Governorate. \\ ***Infectious Diseases, Department of animal Medicine, Faculty of Veterinary Medicine, Assiut University. \\ Email: $\underline{\text { Huda5380@yahoo.com ; safaamalek80@yahoo.com }}$
}

\section{ABSTRACT}

Received at: 30/3/2014

Accepted: 16/4/2014
The present study was carried out to investigate the prevalence of fascioliasis among 100 cattle and buffaloes of different age and sex in Assiut Governorate. Samples were examined by microscopic examination, Agar Gel Diffusion Test AGDT and ELISA techniques to detect Fasciola species eggs and antibodies, respectively. Prevalence of Fasciola was $8 \%$ by microscopic examination, $32 \%$ by AGDT and $60.86 \%$ by ELISA test. Cattle showed higher prevalence of infection $61.4 \%$ than buffaloes $29.4 \%$. Female cattle and buffaloes were more susceptible to the infection $64.55 \%$ than male $23.8 \%$. Fasciola was more frequently recorded in 2-4 years old cattle and buffaloes $76 \%$ followed by more than 4 years $46.7 \%$ then less than 2 years of age $20 \%$. All positive results with fecal egg examination and AGDT were also positive with ELISA. Serological examination by AGDT and ELISA confirms the microscopical examination. The results of this study revealed that the agar gel diffusion test and ELISA could become a useful tools to diagnose fascioliasis in cattle and buffaloes.

Key words: Fascioliasis, AGDT, ELISA, Assiut, prevalence.

\section{INTRODUCTION}

Haridy et al. (2002); Mas-Coma, et al. (2005) and Soliman (2008) mentioned that fascioliasis is a serious infectious parasitic disease infecting domestic ruminants and humans, tops all the zoonotic helminthes worldwide. In Egypt, animal and human fascioliasis is an endemic clinical and epidemiological health problem.

Lotfy and Hillyer (2003); Dar et al. (2005); El-Shazly et al. (2006) and Periago et al. (2008) mentioned that losses due to animal fascioliasis in Egypt, were estimated at 190 million Livre Egyptienne (LE) annually according to the Egyptian Academy of Scientific Research and Technology Report. Both acute and chronic fascioliasis have been found in almost all governorates and in the reclaimed desert land. Fasciolosis is a widespread parasitosis responsible for immense economic losses in cattle and buffaloes in terms of condemnation of livers, decreased milk and meat production, loss of weight and poor carcass quality. So it was considered an important limiting factor for livestock productivity. It is characterized by sudden death with blood stained froth at the natural orifices in acute cases. Diarrhea, jaundice and bottle jaw are predominant features in chronic cases Solusby (1982); Meaney et al. (2002); Khan et al. (2009) and Kuchai et al. (2011).
Urquhart et al. (1996); Urquhart et al. (2000) and Yildirim et al. (2007) found that detection of Fasciola eggs is simple and confirmatory but it is not a useful diagnostic tool at low levels of adult fluke burden. Also, it cannot detect infection at the prepatent period, because eggs are found in feces when the flukes are already matured (usually between 10 and 14 weeks of infection). By this time, major damages to the liver may have already occurred due to Fasciola enter into the liver parenchyma, cause hemorrhages and damage the tissue that lead to cirrhosis in chronic cases. So, Serological diagnoses have been developed as an alternative approach to fecal egg detection. Serological methods can test a large number of sera at a time and also detect infection earlier than fecal egg examination. There are evidences to show that serodiagnosis can detect the presence of infection as early as 2 weeks after infection. Enzyme Linked Immunosorbent Assay (ELISA) can detect serum antibodies to specific antigens of Fasciola sp. using adult fluke extracts. Santiago and Hillyer, (1988); Fagbemi and Guobadia, (1995); Sampaio-Silva et al. (1996) and Ghosh et al. (2005).

Linh et al. (2003) and Adedokun et al. (2008) revealed that the Agar Gel Diffusion Test (AGDT) could become a useful tool to diagnose fasciolosis in cattle and buffaloes. The test was specific for Fasciola infection because the Paramphistomum antigen did not react with sera from the cattle infected with 
Fasciola sp. They detected that AGDT is also a simple and low cost technique. So, it considered a better test for the herd diagnosis of bovine fasciolosis for veterinarians and other investigators that lack suitable equipment for fecal examination and also have no access to an expensive serological ELISA kit.

Allam, (1992) found relatively high prevalence of Fasciola have been reported along the Nile valley, especially in Lower Egypt. Indeed, in the Northern part of the country, in Abis II village, $44 \%$ and $27 \%$, were detected in cattle and buffaloes, respectively. While, Abdel-Aziz, (1993) showed that the prevalence of fascioliasis was $5.3 \%$ and $3.5 \%$ in cattle and buffaloes, respectively in Assiut. Also, Haridy et al. (1999) found that the prevalence of fascioliasis was $3.5 \%$ and $1.5 \%$ for cattle and buffaloes, respectively in Egypt.

Hussein and Khalifa (2010) found that the prevalence of fascioliasis was $28.6 \%$ in cows, $33.7 \%$ in buffaloes in Qena by coprological examination. Also, Hamed, et al. (2013) detected that the prevalence of fascioliasis was $4.4 \%$ by microscopic examination of buffaloes in Assiut. While, Abdo (2014) reported that the prevalence of fascioliasis by using fecal examination (sedimentation technique) among cattle and buffaloes was $7.41 \%$ and $11 \%$, respectively in Assiut governorate. The present study aimed to spot light on the evaluation of the fecal egg examination, AGDT and ELISA in the determination of the prevalence of bovine fascioliasis in Assiut Governorate.

\section{MATERIALS and METHODS}

A survey was conducted during May 2012 to December 2013 to screen the prevalence of fascioliasis in cattle and buffaloes in Assiut. A total of 100 fecal and blood samples were collected from cattle $(n=83)$ and buffaloes $(n=17)$ of different ages groups (Up to 2 years, 2 to 4 years and more 4 years) Bhutto et al. (2012).

\section{Preparation of feacal samples:}

Fecal samples were collected in a suitable air tight containers such as plastic bags. The collected samples were labeled for breed, sex and age and placed in cool boxes and transported to the laboratory for examination and stored at $5^{\circ} \mathrm{C}$. All samples collected were examined within $36 \mathrm{~h}$. Fecal samples were examined by direct smear, flotation and sedimentation techniques for the presence of fluke eggs (Urquhart et al., 1996).

\section{Preparation of blood samples:}

A $10 \mathrm{ml}$ of whole blood samples were taken from Jugular vein of each cattle and buffaloes to serum tubes and was allowed to clot. Sera were separated by centrifugation at $3000 \mathrm{r} / \mathrm{min}$ for 15 minutes after being kept in the refrigerator overnight. Sera were kept at $-20 \mathrm{C}^{\circ}$ until used.

Antigen preparation from adult Fasciola worms according to (Linh et al., 2003):

Adult worms of Fasciola sp. (Figure 4) were collected from the bile ducts of infected slaughtered cattle and buffaloes. The worms were washed with physiological saline and stored at $-20^{\circ} \mathrm{C}$ until examination. The antigen was prepared by homogenizing $0.1 \mathrm{~g}$ of each adult fluke for 30 minutes in $5 \mathrm{~mL}$ of physiological saline (Figure 3). The emulsion was then frozen and thawed twice and centrifuged at 5,000 rpm for $30 \mathrm{~min}$. The supernatant of each emulsion was used as the antigen (Yoshihara et al., 1981).

\section{Agar gel diffusion test:}

$15 \mathrm{~mL}$ of $1 \%$ agarose solution (Bioshop ${ }^{\circledR}$ Canada Inc., Burlington, ON. L7L 6A4) in 8\% saline was poured into a Petri dish $9 \mathrm{~cm}$ in diameter. Several wells were prepared in the agarose gel at a distance of $3 \mathrm{~mm}$ between the wells. Undiluted and untreated serum was used in this study. Each well in the gel was filled with the antigen or serum to be tested (Figure 6). The dish was kept in a moist chamber at room temperature for 4 days and the reaction was observed daily. When a distinct precipitin line was found in the gel, the serum was considered to have the antibody against fasciolosis (Linh et al., 2003).

Enzyme Linked Immunosorbent Assay (ELISA) technique: according to (Voller et al., 1977).

\section{Antigen preparation from dult Fasciola sp worms according to (Moazeni et al., 2005):}

Coating of the plate with diluted antigen: Flat bottom 96 well plate of ELISA were sensitized over night with $200 \mu$ of diluting antigen (1: 50) with Phosphate buffer saline (PBS) PH 9.2 in each well $[100 \mu 1$ antigen with $100 \mu \mathrm{l}$ carbonate - bicarbonate buffer $0.1 \mathrm{M}$ of PH 9.6 per well $(1: 1)]$. Then washing the plate 3 times with washing buffer. The Plate wells were blocked with $5 \%$ bovine serum albumin (Spectrum, Egyptian company for Biotechnology) (200 $\mu \mathrm{l}$ in each well). Blocked plate was incubated 1 hour at $37 \mathrm{C}^{\circ}$. Then the plate was washed 3 times with washing buffer. Then addition of the serum, $100 \mu \mathrm{l}$ of diluted serum samples (1:50) with Phosphate buffer saline (PBS) PH 7.2 were added in each well and incubated 30 minutes at room temperature. After incubation the plate was washed 5 times with washing buffer. Then Enzyme conjugate (Rabbit Anti-bovine ( $\mathrm{IgG}$ ) (Biomedical lab. Inc.) is diluted to $1: 500$ with diluting solution (P. B. S.). Then $100 \mu 1$ of diluted enzyme conjugate were transferred to each well and incubated for 1 hour at 37Co. After incubation, plate was washed 5 times with washing buffer. The plate was washed and substrate 3, 3, 5, 5 tetramethyl Benzidine dihydrochloride (TMB) liquid 
contain (hydrogen peroxide) (Bioshop ${ }^{\circledR}$ Canada Inc., Burlington, ON. L7L 6A4) was added in each well and the plate was incubated in the dark for about 30 minutes at room temperature. Then stopping of the reaction, The color reaction was stopped with $50 \mu \mathrm{l}$ $0.1 \mathrm{M}$ sulphoric acid per well. Reading of the plate, color changes were measured in ELISA reader at $450 \mathrm{~nm}$ filter. The optical density in each well of the plate was read with a spectrophotometer and the data were stored on a microcomputer.

\section{STATISTICAL ANALYSIS}

Pearson Chi-square Test was used to compare the effect of breed, sex and age on the prevalence of fascioliasis in cattle and buffaloes.

\section{RESULTS}

Out of the 100 cattle and buffaloes examined for Fasciola species $8 \%(8 / 100)$ were positive by microscopic examination (Figure 5), 32\% (32/100) by Agar Gel Diffusion Test (AGDT). While antibody detection by ELISA tests resulting in a prevalence of fascioliasis was $60.87 \%(56 / 92)$ by ELISA (Table 1$)$.
In some cases, antibody against the Fasciola sp. was detected even though eggs were not detected in the feces. Fecal egg examination failed to detect (24) $24 \%$ of the positive samples detected by AGDT and failed to detect $52.17 \%$ (48/92) detected by ELISA. All positive results with fecal egg examination and AGDT were also positive with ELISA.

During this study, 83 cattle and 17 buffaloes were examined of which $51(61.4 \%)$ of cattle and 5 $(29.4 \%)$ of buffaloes were found to be infected with Fasciola in Assiut. Overall infection rate was 56 (56\%). High significant differences were found in infection rate with regard to the host breed, cattle showed higher prevalence of infection $(61.4 \%)$ than buffaloes (29.4\%) (Table 2). Also, High significant differences were recorded in female cattle and buffaloes which were more susceptible to the infection (64.55\%) than male (23.8\%) (Table 3$)$. High significant difference of fasciolosis was more frequently recorded in 2-4 years old cattle and buffaloes $(76 \%)$ followed by more than 4 years (46.7\%) then less than 2 years of age $(20 \%)$ (Table 4).

Table 1: Comparison of AGDT (Agar gel diffusion test) and ELISA with microscopic examination for detecting Fasciola in cattle and buffalo.

\begin{tabular}{cccc}
\hline Detection methods & No. of examined animals & Positive samples & Prevalence (\%) \\
\hline Microscopic examination & 100 & 8 & $8 \%$ \\
\hline Agar gel diffusion test & 100 & 32 & $32 \%$ \\
\hline ELISA & 92 & 56 & $60.87 \%$ \\
\hline
\end{tabular}

Table 2: Prevalence (\%) of fasciolosis in cattle and buffaloes according to breed

\begin{tabular}{cccccc}
\hline \multirow{2}{*}{ Breed } & No. of examined animals & Positive samples & Prevalence (\%) & \multirow{2}{*}{$\chi^{2}$} & P \\
\cline { 1 - 4 } Cattle & 83 & $51^{* *}$ & $61.4 \%$ & \multirow{2}{*}{7.29} & 0.01 \\
\cline { 1 - 4 } Buffalo & 17 & 5 & & \\
\cline { 1 - 4 } Total & 100 & 56 & $56 \%$ & & \\
\hline
\end{tabular}

Table 3: Prevalence (\%) of fasciolosis in cattle and buffaloes according to sex

\begin{tabular}{|c|c|c|c|c|c|}
\hline Sex & No. of examined animals & Positive samples & Prevalence (\%) & $x^{2}$ & $\mathrm{P}$ \\
\hline Male & 21 & 5 & $23.8 \%$ & \multirow{3}{*}{12.04} & \multirow{3}{*}{0.01} \\
\hline Female & 79 & $51 * *$ & $64.56 \%$ & & \\
\hline Total & 100 & 56 & $56 \%$ & & \\
\hline
\end{tabular}

Table 4: Prevalence (\%) of fasciolosis in cattle and buffaloes according to age

\begin{tabular}{|c|c|c|c|c|c|}
\hline Age & $\begin{array}{l}\text { No. of examined } \\
\text { animals }\end{array}$ & Positive samples & Prevalence (\%) & $x^{2}$ & $\mathrm{P}$ \\
\hline Up to 2 years & 20 & 4 & $20 \%$ & \multirow{4}{*}{19.235} & \multirow{4}{*}{0.01} \\
\hline $2: 4$ years & 50 & $38 * *$ & $76 \%$ & & \\
\hline More than 4 years & 30 & 14 & $46.67 \%$ & & \\
\hline Total & 100 & 56 & $56 \%$ & & \\
\hline
\end{tabular}




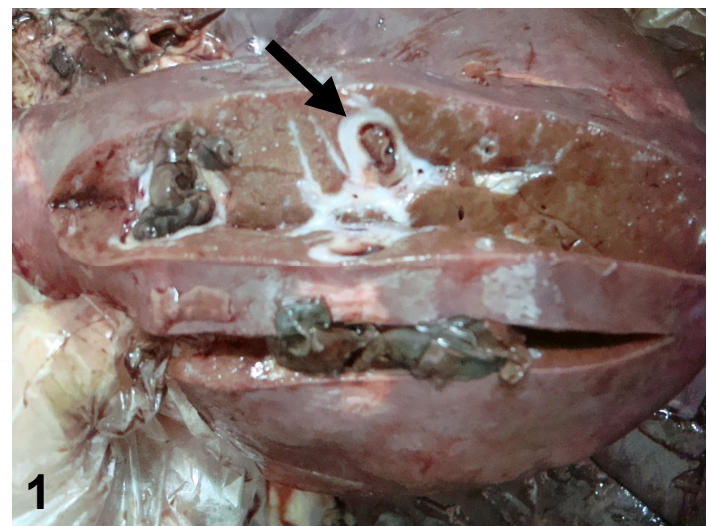

Figure 1: Fasciola infected bovine liver. Note fibrosis and thickening of the wall of bile duct (arrow). Liver flukes also can be seen protruding from cut bile ducts.

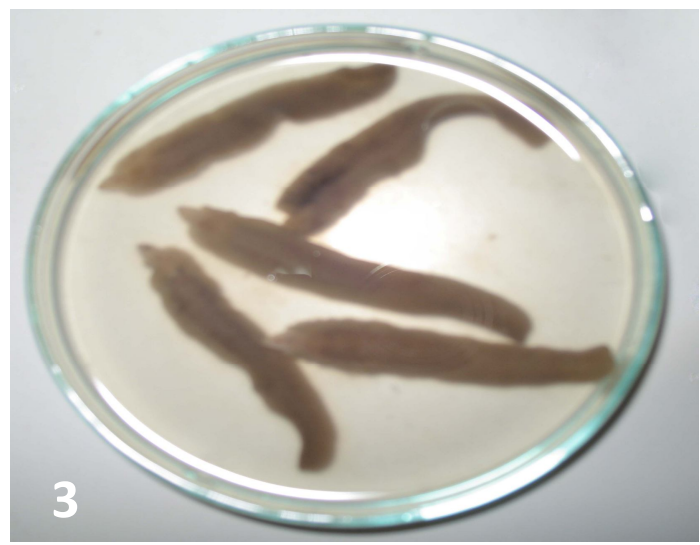

Figure 3: Adult Fasciola worms recovered from an infected bovine liver washed by physiological saline in Petri dish.

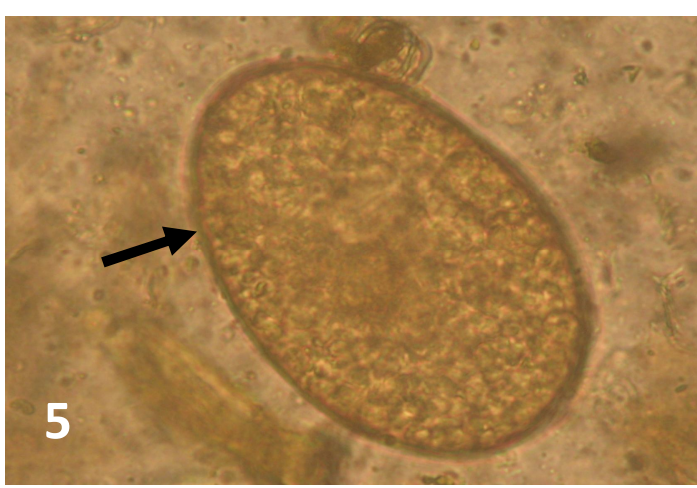

Figure 5: Showed Fasciola species egg (40x magnification).

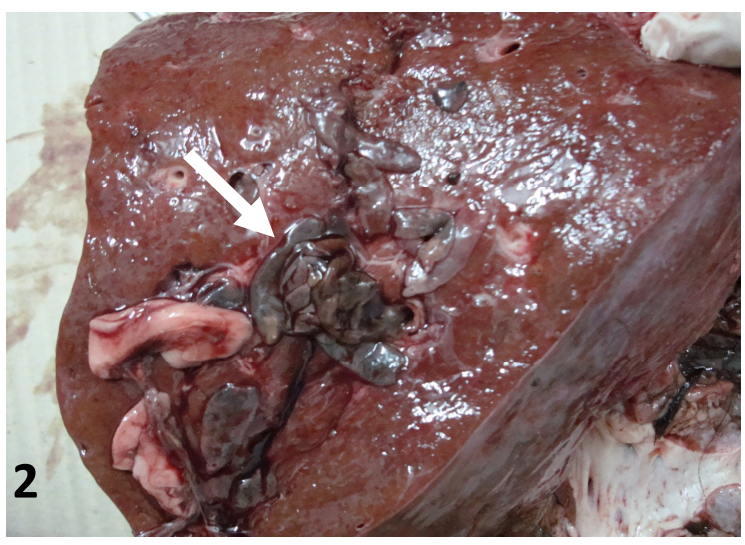

Figure 2: Showed severe infestation of liver with Fasciola spp. worms (arrow).

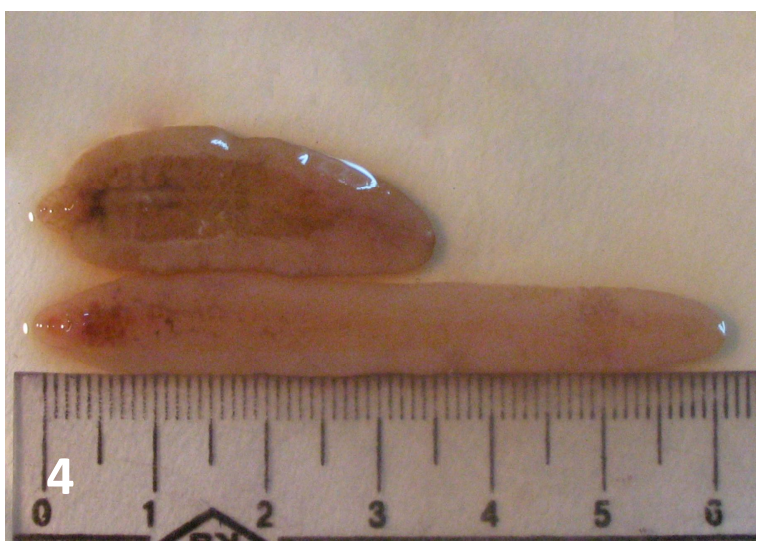

Figure 4: Adult Fasciola worms recovered from an infected bovine liver. Worms are large and leaf shaped (approximately $1 \mathrm{~cm} \times 6 \mathrm{~cm}$ ).

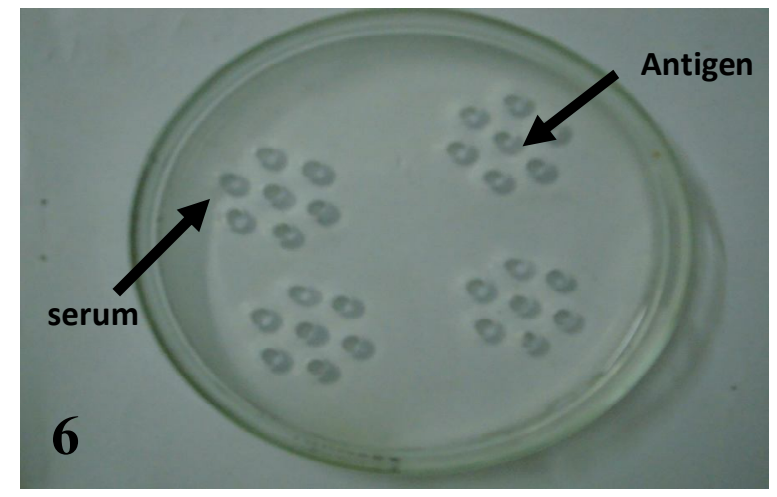

Figure 6: Agarose gel with antigen and test sera in Petri dish 


\section{DISCUSSION}

Vercruysse et al. (1988); Bhattacharya and Laha (1995); Torgerson (1999) and Dar et al. (2005) stated that fascioliasis is asymptomatic disease in most animal cases, but it has substantial effects on milk production and a reduction in food conversion efficiency with reduced weight gain leading to high morbidity and mortality with heavy economic losses.

In the present study, the prevalence of fascioliasis in cattle and buffaloes was $8 \%$ by microscopic examination, $32 \%$ by Agar Gel Diffusion Test (AGDT) and $60.86 \%$ by ELISA tests (Table 1 ). The high prevalence of fascioliasis in this study may be due to insufficient treatment and control measures and irregular usage of anthelmintics might have been responsible for the overall high prevalence of Fasciola species.

This result was similar to that reported by, Mahmoud (1984) 68.9\% in Behera, Samaha (1989) 68.8\% in Alexandria, Keyyn et al. (2005) 28.4- 63.8\% in Tanzania, Yildirim et al. (2007) 65.2\% in Turkey and Adedokun et al. (2008) 58.5\% in Nigeria.

Our study revealed that the prevalence of Fasciola infestation in the examined animals was generally high in comparison with that recorded by Ayoub (1983) 30.7\% in Gharbia, Salem et al. (1990) 29.7\% in Beni- Suef, Mansour (1994) $8.44 \%$ in Cairo abattoir, Abdel-Rahman, (2002) 14\% in Egypt, ElShazly et al. (2002) $12.31 \%$ in Dakahlia Governorate Bhutto et al. (2002) 4\% in Sindh, Waruru et al. (2004) $31.5 \%$ in Kenya, Morsy et al. (2005) $20 \%$ in AL-Fayoum and Nossair and Abdella (2014) 9.8\% in Behera Province. This variation may be attributed to the difference in the study locality and the technique used for detection of the fasciola infestation.

In this study, the results revealed that serodiagnosis by AGDT and ELISA were more sensitive than fecal examination for detection of fascioliasis which may be due to low numbers of egg in the fecal samples, possibly as a result of low worm burden or occlusion of the gastrointestinal tracts by debris (Urquhart et al., 1996). Low sensitivity of microscopic examination could also be as a result of inability of the fecal examination to detect of Fasciola sp. eggs in animals at the early stages of infection. It could possibly be due to intermittent emptying of the gall bladder into the digestive tract. Eggs would be detected only when the fluke is present and the infection is patent.

Adedokun et al. (2008) and Salam et al. (2009) detected that fecal examination was not enough for diagnosis of fascioliasis while AGPT detected more animals with Fasciola $s p$. infection than the microscopical examination. So, AGPT is the suitable method for diagnosing the fasciolosis in early stages, based on the detection of antibodies. Although, AGPT is less sensitive than other serological tests like ELISA, The use of the precipitating antibody test in the diagnosis of Fasciola gigantica has also been shown not to cross-react with antigen of other trematodes Linh et al. (2003). Serological techniques are that they can be easily applied to a large number of samples at once using AGDT or ELISA.

Guobadia and Fagbeni (1996) stated that serodiagnosis of fascioliasis was the good diagnostic assay for detection of early prepatent and active infections. Whereas diagnosis by fecal examination was not possible until 9-10 weeks post infestation, during that time a lot of damage would have been done to the animal. The indirect ELISA is clearly more sensitive than the fecal examination partly because antibodies are present approximately 8 weeks before the infection matures and eggs are shed in the feces, so early detection of infestation is very important because it encourage early chemotherapy.

This study revealed that the prevalence of Fasciola was $61.4 \%$ in cattle and $29.4 \%$ in buffaloes (Table 2). Cattle showed higher prevalence of infection than buffaloes. Our results are in agreement with previous studies conducted with El-Sherif et al. (1959) who revealed $22 \%$ and $13 \%$ in cattle and buffaloes, respectively in Alexandria, Zaki et al. (1965) 15.9\% and $10.9 \%$ in cattle and buffaloes, respectively in El Gharbia Governorate. Similarly, (Monib, 1977) found that prevalences were $30.3 \%$, and $24.3 \%$ in cattle, and buffaloes, respectively in Assiut Governorate, Abdel Aal et al. (1999) found that the Fasciola infestation rates was $(5.3 \%)$ in cattle and $(3.7 \%)$ in buffaloes in lsmailia province, Raza et al. (2007) reported 9\% in cattle and $4 \%$ in buffaloes in Pakistan and Eslami et al. (2009) who recorded that fecal samples of $32.1 \%$ of cattle, $17 \%$ of buffaloes harbored Fasciola egg. This may be due to differences in the immune response of cattle and buffaloes during infestation with Fasciola sp. as well as higher resistance of buffaloes than cattle due to their lower fluke burden or the delayed migration or suppressed development of flukes in buffaloes in compared with cattle (Molina, 2005).

In the present study, female cattle and buffaloes were more susceptible to fascioliasis $(64.55 \%)$ than male (23.8\%) (Table 3). This was in agreement with that described by Phiri et al. (2005) who reported significantly higher prevalence rates of fascioliasis in females than males, Yildirim, et al. (2007) who found that the fascioliasis was $(70.7 \%)$ in females and (47.8\%) in males, Salam et al. (2009) who stated that a higher infection rate in females (15.4\%) as compared to males (6.4\%), Kuchai et al. (2011) who noticed that the prevalence of fascioliasis was higher in females $(46.42 \%)$ than males $(38.46 \%)$ and Abdo 
(2014) who mentioned that female cattle and buffaloes were more susceptible to fascioliasis $(10.95 \%)$ and $(4 \%)$ than male $(5.30 \%)$ and $(0 \%)$, respectively in Assiut governorate. These results may be due to the social practice of keeping male animals under good managemental conditions for fattening and breeding purpose as compared with the females which kept for breeding and milk productions.

In the present study, fascioliasis was more frequently recorded in 2-4 years old cattle and buffaloes (76\%) followed by more than 4 years $(46.7 \%)$ then less than 2 years of age $(20 \%)$ (Table 4). This was in agreement with that described by Kuchai et al. (2011) who noticed that a higher infection rate was recorded in younger ( $>3$ years) buffalos $(45.83 \%)$ than in adult ones $(40 \%)$.

Animals over two years old were significantly more frequently affected than those under 2 years. Similar findings were reported previously by several researchers Shrestha et al. (1992), Ghirmire and Karki (1996), Abdel Aal et al. (1999), Maqbool et al. (2002), Sanchez-Andrade et al. (2002), Marques and Scroferneker (2003), Keyyn et al., (2005), Yildirim et al. (2007), Salam et al. (2009) and Fatima et al., (2012). Also, Nossair and Abdella (2014) found that the highest prevalence was observed in the age group $2-4$ years $(18.18 \%)$ followed by the age group $>4$ years $(5.88 \%)$ and lastly the age group $(<2$ years $)$ $(4.76 \%)$. Many workers have reported an increased incidence of fasciolosis in buffaloes and cattle with advancing age, the higher incidence in older animals might be due to lowering of resistance due to grazing more frequently from pasture which enhance the possibility of infection with Fasciola encysted metacercariae or may be attributed to that the lifespane of fasciola takes longer time to produce the eggs (diagnostic stages) in adult age, or may be due to several times of exposure to the infestation than young.

\section{CONCLUSION}

We concluded that serodiagnosis of fascioliasis by agar gel diffusion test and ELISA were more sensitive than fecal examination. AGDT could be a useful, economic technique for herd diagnosis.

\section{REFERENCES}

Abdel Aal, A.A.; Abou-Eisha, A.M. and El-Sheary, M.N. (1999): "Prevalence of fascioliasis among man and animals in Ismailia province." Assiut Vet. Med. J. Vol 41(81): 141-152.

Abdel-Aziz, N.M. (1993): "Incidence and public health importance of fascioliasis in slaughtered animals in Assiut Province." M.Sc. Thesis, Faculty of Veterinary Medicine, Assiut University, Egypt.
Abdel- Rahman, A.A.H. (2002): "Serological investigation of some zoonotic diseases in cattle." Ph.D. Thesis, (Zoonoses), Fac. Vet. Med. Alex. Univ.

Abdo, B.R.N. (2014): "Epidemiological studies on Fascioliasis in Assiut and New Valley Governorates." Ph. D. V. Sc. Thesis Animal Hygiene and Zoonoses Department, Faculty of Vet. Medicine, Assiut University.

Adedokun, O.A.; Ayinmode, A.B. and Fagbemi, B.O. (2008): "A comparative study of three methods for detecting Fasciola infections in Nigerian cattle." Veterinarski Arhiv, 78 (5): 411-416.

Allam, A.F.M.B. (1992): "Studies on the LymnaeaFasciola (host-parasite) relationships in Abis area." Ph.D. Thesis, High Institute of Public Health, Alexandria University, Egypt.

Ayob, A.A.M. (1983): "The interpretation of different tests used for estimation of parasitic state of Fasciola gigantica in Gharbia Governorate." M. Vet. Sci. Thesis, Faculty of Vet. Medicine, Cairo Univ.

Bhutto, B.; Phullan, M.S.; Rind, R. and Soomro, A.H. (2002): "Prevalence of gastrointestinal helminthes in buffalo calves." Online Bio. Sci., (2): 43-45.

Bhutto, B.; Arijo, A.; Phullan, M.S. and Rind, R. (2012): "Prevalence of Fascioliasis in Buffaloes under Different Agroclimatic Areas of Sindh Province of Pakistan." Int. J. Agric. Biol., 14 (2): 241-245.

Bhattacharya, D. and Laha (1995): "Immunity, Immunodiagnosis and immuno-prophylaxis of liver fluke disease." Asian Livestock, (5): 54-55.

Dar, Y.D.; Rondelaud, D. and Dreyfuss, G. (2005): "Update of fasciolosis- transmitting snails in Egypt (review and comment)." J. Egypt Soc. Parasitol. 35(2): 477-490.

El-Shazly, A.M.; El-Nahas, H.A.; Soliman, M.; Sultan, D.M.; Abedl Tawab, A.H. and Morsy, T.A. (2006): "The reflection of control programs of parasitic diseases upon gastrointestinal helminthiasis in Dakahlia Governorate." Egypt J. Egypt Soc. Parasitol. 36(2): 467-480.

EL-Shazly, A.M.; El-Wafa, S.A.; Haridy, F.M.; Soliman, M.; Rifaat, M.M. and Morsy, T.A. (2002): "Fascioliasis among live and slaughtered animals in nine centers of Dakahlia Governorate." J. Egypt. Soc. Parasitol. 32(1): 47-57.

El-Sherif, A.F.; Abdou, A.H. and El-Sawi M.F. (1959): "The incidence of parasitic infestation among the farm animals of Faculty of Agriculture, University of Egypt." Vet. Med. Assoc. 19, 19-21.

Eslami, A.; Hosseini, S.H. and Meshgi, B. (2009): "Animal Fasciolosis in North of Iran." Iranian J. Publ. Health, 38 (4): 132-135. 
Fagbemi, B.O. and Guobadia, E.E. (1995): "Immunodiagnosis of fasciolosis in ruminants using a 28-kDa cysteine protease of Fasciola gigantica adult worms." Vet. Parasitol. 57, 309-318.

Fatima, M.; Chishti, M.Z.; Ahmad, F. and Lone, B. A. (2012): "Epidemiological Study of Fasciolosis in Cattle of Kashmir Valley." Advances in Biological Research 6 (3): 106-109.

Ghirmire, N.P. and Karki, N.P.S. (1996): "Prevalence of fascioliasis and efficacy of various anthelmintics in buffaloes of Rural Kathamandu vetcon.” N. U. A. pp. 43.

Ghosh, S.; Rawat, P.; Velusamy, R.; Joseph, D.; Gupta, S.C. and Singh, B.P. (2005): "27 kDa Fasciola gigantica glycoprotein for the diagnosis of prepatent fasciolosis in cattle." Vet. Res. Commun., (29): 123-135.

Guobadia, E.E. and Fagbeni, B.O. (1996): "detection of circulating Fasciola gigantica antigen in experimental and natural infections of sheep with fascioliasis. Vet. Parasitol., (65): 29-39.

Hamed, M.I.; Abd Ellah, M.R. and Rateb, H.Z. (2013): "Helmenthiasis: prevalence and associated determinants in Buffaloes Farms in Assiut, Egypt." International Congress of Mediterranean Federation of health and production of ruminants.

Haridy, F.M.; Ibrahim, B.B.; Morsy, T.A. and ElSharkawy, I.M. (1999): "Fascioliasis an increasing zoonotic disease in Egypt." Journal of the Egyptian Society of Parasitology 29 (1): 35-48.

Haridy, F.M.; Morsy, T.A.; Gawish, N.I.; Antonios, T.N. and Abdel Gawad, A.G. (2002): "The potential reservoir role of donkeys and horses in zoonotic fascioliasis in Gharbia Governorate, Egypt.' J. Egypt. Soc. Parasitol. 32(2): 561-570.

Hussein, A.A. and Khalifa, R.M.A. (2010): "Fascioliasis prevalences among animals and human in Upper Egypt." Journal of King Saud University (Science) 22, 15-19.

Keyyn, J.D.; Kassuku, A.A.; Msalilura, L.P.; Monrad, $J$. and Kyvsgaard, N.C. (2005): "Cross section prevalence of helminth infection in cattle on traditional, small-scale and large scale dairy farms in Iringa District, Tanzania." Veterinary Research Communications, (30): 45-55.

Khan, M.K.; Sajid, M.S.; Khan, M.N.; Iqbal, Z. and Iqbal, M.U. (2009): "Bovine fasciolosis: Prevalence, effects of treatment on productivity and cost benefit analysis in five districts of Punjab, Pakistan." Res. Vet. Sci., (87): 70-75.

Kuchai, J.A.; Tak, H.; Chishti, M.Z.; Rasool, M.; Dar, S.A. and Ahmad, J. (2011): "Impact of season, sex, age, and agro-ecology on the prevalence of fascioliasis in buffalos of
Ladakh." Online Journal of Animal and Feed Research 1 (6): 263-266.

Linh, B.K.; Thuy, D.T.; My, L.N.; Sasaki, O. and Yoshihara, S. (2003): "Application of Agar Gel Diffusion Test to the Diagnosis of Fasciolosis in Cattle and Buffaloes in the Red River Delta of Vietnam.” J. A. R. Q. 37 (3): $201-205$.

Lotfy, W.M. and Hillyer, G.V. (2003): "Fasciola species in Egypt." Exp. Pathol. Parasitol. 6 (11): 9-22.

Mahmoud, A. (1984): "Some studies on fascioliasis as animal problem." PhD Thesis, Department of Parasitolosgy, Faculty of Veterinary Medicine, Alexandria University.

Maqbool, A.; Hayat, C.S.; Akhtar, T. and Hashmi, H.A. (2002): "Epidemiology of fasciolosis in buffaloes under different managemental conditions." Veterinarski Arhiv 72 (4), 221-228.

Mansour, N.K. (1994): "Incidence of some zoonotic agents and tuberculosis in slaughtered buffaloes (Bubalus bubalis) Vet. Med. J. Giza, 43 (2): 231-239.

Marques, S.M.T. and Scroferneker, M.L. (2003): "Fasciola hepatica infection in cattle and buffaloes in the State of Rio Grande do Sul, Brazil" Parasitol Latinoam 58: 169 - 172.

Mas-Coma, S.; Bargues, M.D. and Valero, M.A. (2005): "Fasciolosis and other plant-borne trematode zoonoses." Inter. J. Parasitol., (35): 1255-1278.

Meaney, M.; Fairweather, I.; Brennan, G.P.; Ramasamy, P. and Subramanian, P.B. (2002): "Fasciola gigantica: tegumental surface alterations following treatment in vitro with the sulphoxide metabolite of triclabendazole." Parasitology Research, 88 (4): 315-325.

Moazeni, M.; Gaur, S.N.S. and Shahangian, A. (2005): "Cross reactivity between ES and somatic antigens of Fasciola spp in enzyme linked immunosorbent assay." Iranian Journal of Veterinary Research, University of Shiraz, 6 (2): $62-65$.

Molina, E.C. (2005): "Comparison of host -parasites relationships of $F$. gigantica." $\mathrm{PhD}$ thesis, James Cook University.

Monib M.E.M. (1977): "Study on some helminth parasites of ruminants in Assiut Governorate." M.Sc. Thesis, Faculty of Veterinary Medicine, Assiut University, Egypt.

Morsy, T.A.; Salem, H.S.; Haridy, F.M.; Rifaat, M.M.; Abo-Zenadah, N.Y. and Abdel El-Kadi, M. (2005): "Farm animals fascioliasis in Ezbet El- Bakly (Tamyia center) Al- Fayoum Governorate." J. Egypt Soc. Parasitol 35 (3): 825-832.

Nossair, M.A. and Abdella, D.E. (2014): "Serological Detection of Fasciola hepatica Antibodies among Cattle and Human in Behera Province, 
West Delta, Egypt." Alexandria Journal of Veterinary Sciences 40: 16-23.

Periago, M.V.; Valero, M.A.; El Sayed, M.; Ashrafi, K.; El Wakeel, A.; Mohamed, M.Y.; Desquesnes, M.; Curtale, F. and Mas-Coma, S. (2008): "First phenotypic description of Fasciola hepatica/Fasciola gigantica intermediate forms from the human endemic area of the Nile Delta, Egypt." Infect. Genet. Evol. 51-58.

Phiri, A.M.; Phiri, I.K.; Sikasunge, C.S. and Monrad, $J$. (2005): "Prevalence of fasciolosis in Zambian cattle observed at selected abattoirs with emphasis on age, sex and origin." J. Vet. Med. B, 52: 414-416.

Raza, M.A.; Iqbal, Z.; Jabbar, A. and Yaseen, M. (2007): "Point prevalence of gastrointestinal helminthiasis in ruminants in southern Punjab, Pakistan." J. Helminthol. (81): 323-328.

Salam, M.M.; Maqbool, A.; Naureen, A. and Lateef, M. (2009): "Comparison of different diagnostic techniques against Fasciolosis in Buffaloes." Veterinary World, 2(4): 129-132.

Salem, A.A.; Shawkat, M.E.; El- Seify, M.A. and Khateib, A. (1990): "Incidence and seasonal prevalence of fascioliasis in Beni-Suef, Egypt." Assiut Vet. Med. J., 22(44): 62-67.

Samaha, H.A. (1989): "The zoonotic importance of Fascioliasis in Abbis, Alexandria Governorate." Assiut Vet. Med. J. 21 (42): 118-124.

Sampaio-Silva, M.L.; Correia Da Costa, J.M.; Vaiana Da Costa, A.M.; Pires, M.A.; Lopes, S.A.; Castro, A.M. and Monjour, D.L. (1996): "Antigenic components of excretory-secretory products of adult Fasciola hepatica recognized in human infections." Am. J. Trop. Med. Hyg. (54): 146-148.

Sanchez-Andrade, R.; Paz-Silva, A.; Suarez, J.L.; Panadero, R.; Pedreira, J.; Lopez, C.; DiezBanos, P. and Morrondo, P. (2002): "Influence of age and breed on natural bovine fasciolosis in an endemic area (Galicia, NW Spain)." Vet. Res. Commun., 26: 361-370.

Santiago, N. and Hillyer, G.V. (1988): "Antibody profiles by EITB and ELISA of cattle and sheep infected with Fasciola hepatica." J. Parasitol. (74): 810-818.
Shrestha, E.K.; Thakur, R.P.; Dhakal, I.P. and Mahato, S.N. (1992): "Prevalence and treatment of fascioliasis in cattle and buffaloes in Dhankuta district." Vet. Review, 7: 47-49.

Soliman, M.F.M. (2008): "Epidemiological review of human and animal fascioliasis in Egypt." J. Infect. Developing Countries 2(3): 182-189.

Solusby, E.J.L. (1982): "Helminthes, Arthropods and Protozoa of Domesticated animals." Bailliere, Tindal and Cassel, London, 809 spp.

Torgerson, P. and Claxton, J. (1999): "Epidemiology and control. In: Fascioliosis." Ed. Dalton, J.P.: CABI Publishing, 1st ed. Oxon, Wallingford, UK p. 113-149.

Urquhart, G.M.; Armour, J.; Duncan, J.L.; Dunn, A.M. and Jennings, F.W. (1996): "Veterinary Parasitology, 2nd ed., Blackwell Science, London.” p. 110-307.

Urquhart, G.M. (2000): "Veterinary Parasitology" ELBS 1st Edition London.

Vercruysse, J.; Taraschewski, H. and Voigt, J. (1988): "Main clinical and pathological signs of parasitic infections in domestic animal." In: Parasitology in Focus. Ed, $\mathrm{H}$ Mehlhorn: Springer-Verlag; 1st ed. Berlin, p. 494.

Voller, A.; Bidwell, D.E., and Bartlett, A. (1977a): "The Enzyme Linked Immunosorbent Assay (ELISA).” pp. 24-26. Flow-line Publications, Guernsey.

Waruru, R.M.; Mutune, M.N. and Otieno, R.O. (2004): "Gastrointestinal parasites infection of sheep and goats in semiarid areas of Machakos District, Kenya." Bull. Anim. Hlth. Prod. Afr. (53): 25-34.

Yildirim, A.; Ica, A.; Duzlu, O. and Inci, A. (2007): "Prevalence and risk factors associated with Fasciola hepatica in cattle from Kayseri province, Turkey." Revue Méd. Vét., 158 (12): 613-617.

Yoshihara, S.; Taira, N. and Suzuki, K. (1981): "Antigenic comparison among several developmental stages of Fasciola sp." Jpn. J. Vet. Sci., (43): 699-707.

Zaki, H.; El-Refaii, A.H. and Saliman, M.K. (1965): "Hematology of normal cattle and buffaloes and those infected with Fasciola gigantica." In: Proceedings of the Sixth Annual Arabian Veterinary Congress, Cairo, p. 263. 


\section{دراسة طفيلية وسيرولوجية عن تثخيص الفاشيولا في الأبقار والجاموس في محافظة أسيوط هلى محمد محمد قراعه ، صفاء سيا حسن حسنين}

Email: Huda5380@yahoo.com ; safaamalek80@yahoo.com

أجريت هذه الدر اسة لتحديد نسبة الاصابه بالديدان الكبديه (الفاثشيو لا) لعدد مائه من الأبقار و الجاموس بأعمار و أجناس مختلفة في

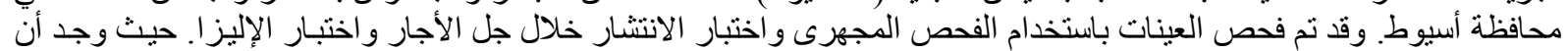

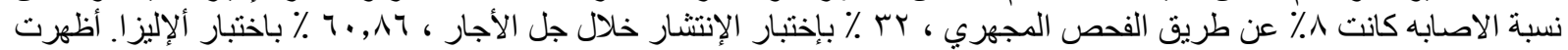

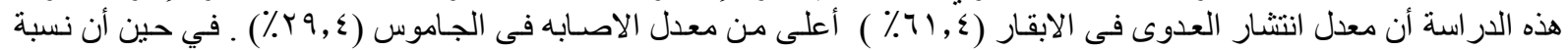

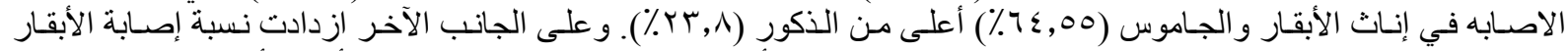

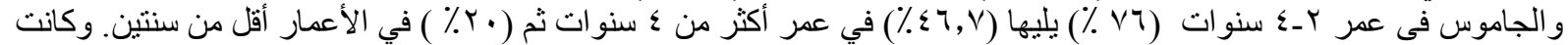

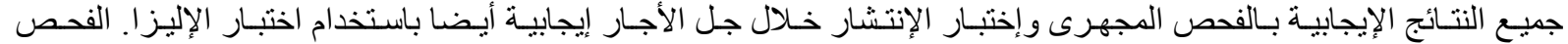

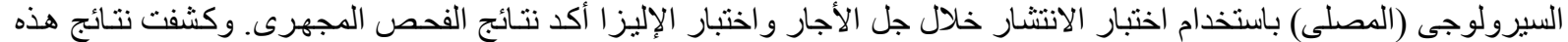

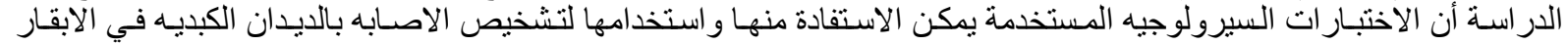

